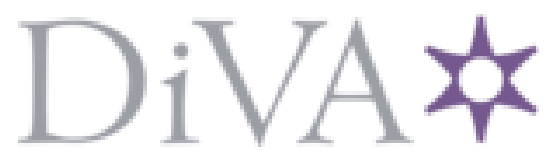

http://www.diva-portal.org

\title{
Postprint
}

This is the accepted version of a paper published in Historical Archaeology. This paper has been peerreviewed but does not include the final publisher proof-corrections or journal pagination.

Citation for the original published paper (version of record):

Holtorf, C. (2017)

The Heritage of Rupture: [ Review of Patina: A Profane Archaeology. Shannon Lee Dawdy, The University of Chicago Press, Chicago, IL, 2016 \& Constructing Destruction: Heritage Narratives in the Tsunami City. Trinidad Rico, Routledge, New York, NY, 2016 ].

Historical Archaeology, 51(2): 302-304

https://doi.org/10.1007/s41636-017-0025-3

Access to the published version may require subscription.

N.B. When citing this work, cite the original published paper.

Permanent link to this version:

http://urn.kb.se/resolve?urn=urn:nbn:se:Inu:diva-62498 
Review for Historical Archaeology 2017. The final publication is available at Springer via http://rdcu.be/rppW

\section{The Heritage of Rupture}

Patina. A Profane Archaeology.

Shannon Lee Dawdy

The University of Chicago Press, Chicago and London, 2016. 200pp., USD 27.50 paperback.

Constructing Destruction. Heritage Narratives in the Tsunami City.

Trinidad Rico

Critical Cultural Heritage Series, 12. Routledge, London and New York, 2016. 125pp, USD

84.00 hardcover.

In 2005, the strong gusts of hurricane Katrina brought down a massive tree in St. Anthony's Garden, just behind St. Louis Cathedral in the French Quarter of New Orleans, USA. It hit a marble statue of Jesus, and a thumb and a finger were lost as a result. A few years later, when Shannon Lee Dawdy began excavating in the garden, the rector of the Cathedral was keen to find those fingers. There was some commotion when a student did indeed find a marble finger in the dirt, one week into the excavations. But only when it did not fit to the hand of Jesus, the rector confessed that the fingers had been broken before and were reglued back on, only a few years before Katrina. A light touch of a branch could have brought them down again. He concluded that it would be best to leave those fingers partly missing: "it's a good sign of what was" (Dawdy, 116). It is not lost to Dawdy that this episode represents an apt allegory for the significance of heritage. Both the incomplete hand of Jesus and the finger that wouldn't fit are 'good signs of what was', referencing not only stories of past loss and evoking experiences of pastness in the present but also manifesting ambitions to re-make and effectively repair past trauma.

The two books under review here, then, take up questions of the meaning of heritage and ways of engaging with it in the present. Both centre on disasters that became local and regional ruptures. When hurricane Katrina, on 29 August 2005, hit southern Louisiana it was the third most intense tropical cyclone ever to hit land in the United States. According to Wikipedia, it cost more than 1,200 lives, mostly in New Orleans where a staggering $80 \%$ of the city was flooded. Total property damage across the southern coasts of the US has been estimated to cost US\$ 108 billion. Katrina became a major trauma for the entire southern region of the United States.

Half a year earlier, on 26 December 2004, a major tectonic earthquake had occurred off the west coast of Sumatra, Indonesia. It was the third-largest earthquake ever recorded on a seismograph. According to Wikipedia, the total energy released has been estimated to more than twice the total explosive energy used during all of World War II including both nuclear bombs. The shock triggered a series of tsunamis that killed up to 280,000 people in 14 countries across the Indian Ocean, with Indonesia being hit particularly hardly. In the region of Aceh, the incoming wave was up to $30 \mathrm{~m}$ high. Banda Aceh, with a population of circa 
220,000 at the time, was severely damaged both by the earthquake and the subsequent tsunami. 167,000 lives were lost here alone. Both ruptures shattered continuities and had profound impacts on all aspects of life in the regions affected, including the natural and built environment.

The heritage of rupture is about witnessing loss, the materiality of what is not there. As the case of the finger found in St. Anthony's Garden illustrates, the heritage of rupture can also be about what perhaps never was there in the first place. Absences have often been overlooked by archaeologists in their focus on what has been preserved. But Dawdy puts due attention on patina (indicating loss and pastness), storytelling (bringing the past to life), fakes and invented traditions (pasts made-up), and even ghosts (haunted sites and buildings). Most of that was part of New Orleans long before Katrina, and in that sense rupture has been inherent in the city and is perhaps implied in the very idea of heritage. This sense of rupture is sustained through the patina and pastness of things and also through the stories of what was then and which ghosts are roaming the area now. This past is never really past but very present indeed - so that Dawdy had to discuss in some detail how New Orleans was made old in subsequent presents and how Katrina has been ruining some of that antiquity.

There is another aspect to the heritage of rupture, as Trinidad Rico brings to the fore, with reference to the destructions caused by the tsunami that hit Banda Aceh. The fear of loss lies at the heart of heritage - and given the plethora of heritage legislation and conservation policies, it is unlikely to be lost itself. By the same token, the ubiquity of perceived 'heritage at risk' is not at risk itself. The prospect of rupture mobilises a response of care. Indeed, it once established conservation as the natural task of heritage management. We were told that the endangered heritage needed to be preserved for the benefit of future generations. But as Rico points out (70), risk value is formative for heritage. Yet it does not tend to be addressed in assessments of heritage value or in the associated theory and policy of heritage. Taking responsibility for endangered goods is a seemingly unopposable agenda. However, putting the aim to prevent loss and rupture on a pedastal hides the various social, cultural and political contexts from which heritage management and indeed the very notion of heritage derive. Both Dawdy and Rico successfully unravel some of these contexts in relation to their specific case-studies from opposite regions of the world.

Heritage at risk evokes the future, indeed it colonizes it. What is endangered is to be saved, what was lost is to be re-made. That colonisation is based on the assumption of the future as an unchanging present - a future in which people will thank us for our conservation efforts and in which we will be recognised as responsible ancestors that did the right thing. Given inevitable changes over time in the way contemporary people act, think and valorize in concurrent and consecutive societies, such futures are hardly very sustainable. Ironically, conservation efforts will invariably require continuing adaptation of the heritage to ongoing changes. But the preservation of past fabric, and as Dawdy shows (79) with reference to the old buildings of New Orleans also the preservation of local communities, may actually be best achieved through neglect. Slowly decaying houses add patina to the neighbourhood. To be a real New Orleanian you do not need to be born there but you need to be able to exchange with your neighbours stories about the history of the house in which you live. 
So can there be any mileage for heritage independent of its state of ruination, any further anticipated risk, and the threat of ultimate doom? Rico suggests that there may indeed be room for new forms of heritage, beyond familiar scenarios and global policy frameworks based on notions of loss and possible extinction, and enabling the valorisation of locally grown heritage that was previously marginalized. The tsunami in Banda Aceh had left behind a number of boats on rooftops or far inland, and these have become known as Tsunami boats. They are being maintained by the local communities as witnesses and monuments to the tsunami, attracting tourists at the same time. They are also replacing previously dominant narratives of heritage focussing for example on Banda Aceh's Islamic culture, colonial sea trade, modernization and the Japanese occupation during World War II. In Rico's analysis, tsunami boats are contemporary heritage that "mobilizes destruction as a tool for carving a space in which the conversation about the future of Aceh can carry on less burdened by the past" (Rico, 39). That future is one in which local communities are wiser and more resilient thanks to witnesses of past disasters. Like the ever-present nostalgia in New Orleans's French Quarter, one might say that the purpose of this emerging heritage is not "to roll back time but to goad the future" (Dawdy, 144). There are many links between past and future and between New Orleans and Banda Aceh.

In comparison, the two books are somewhat different even though they have related theoretical concerns and are based on a similar approach to heritage, involving archaeological fieldwork and ethnography. Dawdy presents an ambitious and affordable paperback with The University of Chicago Press. Rico's short study, published in an expensive hardback by Routledge, does perhaps not do full justice to the extensive ethnographic research it is based on but is bolder in some of its conclusions. Both works are however challenging us profoundly in how we think about heritage now and point us into new directions for how we should think about managing heritage in the future.

Most significantly (perhaps surprising for some), neither Rico nor Dawdy show much appetite for heritage sentimentalism. There are few or no tears being dropped for the enormous losses in terms of heritage that the hurricane and earthquake plus tsunami caused. Instead the authors understand destruction and loss in terms of narrative and time, nostalgia and risk value, alterity and chronotopia, ghosts and fetishes. There is much academic maturity in daring to discuss destruction as construction by Rico, and in practicing archaeology as a profanity in the eyes of some colleagues of Dawdy.

For that reason alone, it will be interesting to see how these important works about the impact of natural disasters can be applied to the impact of other disasters such as war, social upheavals, and terrorism. Human resilience is to a large extent cultural resilience. It may turn out that cultural resilience is not so much reliant on the conservation of heritage as on the ability to deal with the loss of heritage. After all, what has been lost may be a good sign of what was.

Cornelius Holtorf

Centre for Applied Heritage

Linnaeus University

39182 Kalmar

Sweden 